\title{
The Derailed Decentered Subject in Sarah Kane's 4.48 Psychosis
}

Presented by:

Lamia Farouk Fahim 



\section{Abstract:}

This article investigates the mental impairment in the postmodernist character/characters in Sarah Kane's play 4.48 Psychosis through the psychoanalytical theories of Jacques Lacan. Sarah Kane is enlisted among the big three of In-Yer-Face theatre British dramatists who invaded our personal spaces with extremism of language and unsettled disturbing emotions shown on stage. Prompted by the fragmented bizarre structure of 4.48 Psychosis and the perplexing and troubling demeanor of its characters, the study with track down the springs of such ruptures and the reasons of deviation from their past course.

The fragmented self in postmodern literature earns its distinction in history through this singular feature of being decentered and its drifting attitude towards the chaotic delusional world. Lacan (1901-1981) is described by Marshall Alcorn in "The Subject of Discourse: Reading Lacan (and beyond) Poststructuralist Contexts" as the founder of the psychological structure of the self on "linguistic and discursive phenomena" and his talent in synthesizing psychoanalytical and poststructuralist concepts is immensely influential. According to the entry on "Jacques Lacan" in the Internet Encyclopedia of Philosophy, Lacan asserted a doctrine that human identity is "decentered" and when the subject's mind chains snap, vents are created by the missing signifier of the Name-of-the- Father, and psychosis is triggered.

Despite the loss of a center, the postmodern subject speaks violence out of a peaceful heart and brutality out of compassionate humanity. In 4.48 Psychosis a destructive physical ache spreads in a subject yearning for love, scary medical notes sound funny and falling black snow, quiet screams and tearless weeps are symptoms of a psychotic subject. The postmodern self is ontologically grounded in love which should be understood as a force that seeks to reunite that which has been separated. 


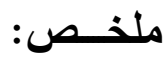

تبحث هذه المقالة التلف الذهني في الثخصية / الشخصيات فيما بعد الحداثة

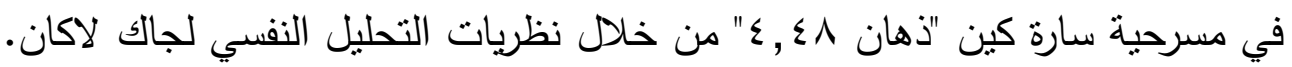
"In- وقد درجت سارة كين ضمن اكبر ثناث كتاب مسرحيين بريطانيين في مسرح" والذين اجتاحوا المساحات الثخصية بتطرف في اللغة وعواطف غير Yer- Face"

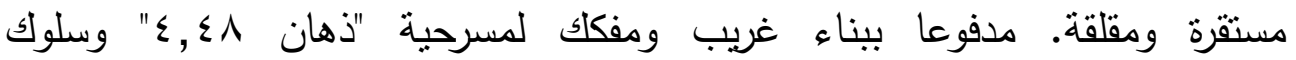
الثخصيات المربك والمتضطرب، يتتبع هذا التحليل تلك التمزقات للوصول لمنابع واسباب خروج الذات عن المسار الذي سلكته في الماضي. حصلت الذات الممزقة فيما بعد الحداثة علي تميزها في التاريخ من خلال

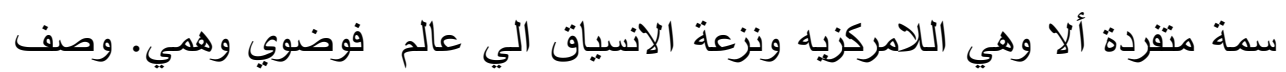
مارشال الكورن لاكان بأنه مؤسس الهيكلة النفسية للذات علي أسس" الظواهر اللغوية والتحاورية "وصارت مهارته في توليف مفاهيم التحليل النفسي وما بعد البنيوية مؤثرة بشكل هائل. ".بناءً علي ما ذكرته موسوعة الانترنت للفلسفة وتحت عنوان "جاك

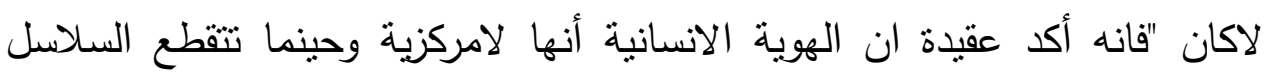
العقلية للذات، تخلق الفجوات بفقدانها للرمز اللغوي" اسم الأب "مسبية الجنو. وبالرغم من سقوط المركز فان الذات فيما بعد الحداثة تتطق بالعنف من قلب

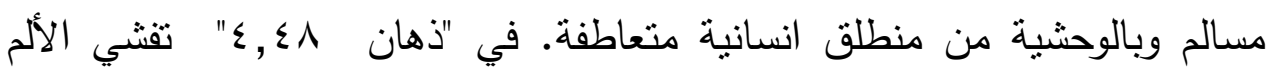
الجسدي المدمر في الثخصية المنلهفة الي الحب وبدت النوتات الطبية المرعبة مثيرة للضحك ـ وصار التلج الاسود المنهمرو الصرخات الصامتة والبكاء غير الدامع أعراضا للذات المضطربة عقلا. ان الذات فيما بعد الحداثة تتتفس الحب الذي يجمع ما تفرق. 


\section{The Derailed Decentered Subject \\ in Sarah Kane's 4.48 Psychosis}

The present thesis investigates the decentered Lacanian subject in Sarah Kane's 4.48 Psychosis (2000) under the psychoanalytical lenses of Lacan's theories which contended that the human unconscious is meshed in language and the rupture of its mind signifying chains triggers psychotic symptoms to emerge as language impairments. Lacan's psychoanalytical studies pour into a poststructuralist linguistic channel giving language prominence as the main standard which measures and determines psychosis; the inadequate relationship between signifiers and signifieds gives rise to fractured flowing scraps of discourse appearing as hovering flowing signs. Moreoyer, at is the foreclosure of the anchoring paternal signifier called the Name-of-the-Father that directly prompts fractures and vents in the psychotic discourse leading to aggressivity, rivalry, delusions and hallucinations. The present thesis is an attempt to comprehend the mainsprings that have led to the agitation of the coherent independent self of the past based on Lacan's theoretical poststructuralist and psychoanalyticalinsights. Furthermore, the study tracks and follows the trail of the Lacanian subject to comprehend the consequences of transforming the self to a mere subject in a fractured linguistic text and the demands that have hurled it over a hazardous detouring course.

Sarah Kane's 4.48 Psychosis reflects a dark derailed psychotic soul erupting with an agitated text that contains no characters, settings or stage directions. The title of the play indicates the early hour of the day when both clarity and desperation visit the mentally-ill person who appears fluctuating in random rapid shifts between her demons, doctors, lovers and imaginative figments of herself in different shapes and stages. Andrew Dickson in The Guardian under his article; "The Strange Thing is We Howled with Laughter" writes that the play "invites the audience to experience a form of psychosis, in which reality dissolves even as it appears" as Kane blurs boundaries wherever she carries us with her characters. The play is permeated 
with "a sequence of elliptical fragments, fractured and emotionally lacerating, it apparently portrayed a mind in the throes of breakdown, raging against doctors who do not (or will not) understand." Dickson adds that "some portions appear to be dialogue" and sections of "a single voice pulsates with anxiety, and another records sardonic clinical notes" or "a bare list of number, strung across the page like a mathematical riddle."

The aggressive violent Lacanian subjects befit the characters of In-Yer-Face theatre as clearly manifested in Sarah Kane's 4.48 Psychosis. Kane's character/characters in the play dwindle along thorny blurry lines of indeterminacy with shriveling sanity and eroding wholeness. Violence is detected in the dark psychological afflictions of the character/characters in 4.48 Psychosis as their mental plight is accompanied by a release of verbal agitated shreds, infliction of self-pain and a compelling death drive. Carolina Sanchez-Palencia Carazo states in " 4.48 Psychosis: Sarah Kane's bewildered fragments" that the "death drive is primarily turned not towards outside (as aggressivity) but towards the subject, that is, it is radically not a drive to "murder", but a drive to "kill oneself"" and she relates aggressivity to "self-loathing" and "self-discrimination" which lead to "selfinflicted pain" (2). Lea Jasmin Gutscher in Revelation or Damnation? Depictions of Violence in Sarah Kane's Theatre states that in Kane's plays "there is just total and utter brutality presented in a very cold, routine-like way. With their bleak and depressing atmosphere, her plays are very hard to digest" (17). She, also, connects the "unspeakable acts of brutality" in Kane's plays with the concept of love; "Kane juxtaposes the presence of evil in the human condition with the characters' craving for love and shows that both violence and love are rooted within the human nature" (98). Kane's psychotic character's unquenched thirst for love and getting connected with her beloved impels self inflicted pain and amidst her torn shredded discourse we hear a clear voice beckoning affections and faith.

The postmodern character in the British theatre manifested in 4.48 Psychosis is psychologically fragmented due to ruptures in the mind signifying chains. Postmodernist subjects are psychologically de-centered via vents, holes and ruptures encountered in their chains of minds. Henke and Middeke in Drama and/after Postmodernism 
have affirmed that "post-modernist thinking most of all equals a loss of faith in a stable, coherent, and knowable self" which influenced both idea of the philosophy and psychology overthrowing "the conscious, rational and autonomous self' (2). The point that distinguishes the psychotic from the normal person is his inability to suture holes in his psyche as his unconscious is woven in linguistic texts. Chiesa, in Subjectivity and Otherness: A Philosophical Reading of Lacan, conceives of subjects as "normal" psychotics who aborted their attempts to "suture" the lack; "Lacan believes that all subjects are potentially psychotics, and can obviate this condition only by means of a 'suture' and from the standpoint of the symbolic structure, psychosis logically precedes "normality", (7). Lacan gave a definition to modern man as fragmentary and delusionally structured and as having the tendency of proliferation as indicated in The Psychoses: The Seminar of Jacques Lacan:

I designated this the discourse of freedom, essential to modern man insofar as he is structured by a certain conception of his own autonomy. I pointed out its fundamentally biased and incomplete [. . .], inexpressible, fragmentary, differentiated, and profoundly delusional nature. I set out from this general parallel to point out to you what, in relation to the ego, is apt, in the subject fallen prey to psychosis, to proliferate into a delusion. (Loc 3255)

The Lacanian subject has a lack, shattered into pieces and rendered vulnerable to psychosis. The shattered voice/voices of Kane's mystifying inexplicable character in 4.48 Psychosis hover(s) on borders not belonging to a definite gender or specific identity. The protagonist expresses that the unified coherent mindful self of the past has receded and been sent to a dark confinement as a new subject erupting with floating fragments that has taken the foreground as exclaimed:

a consolidated consciousness resides in a darkened banqueting hall near the ceiling of a mind whose floor shifts as ten thousand cockroaches when a shaft of light enters as all thoughts unite in an instant of accord body no longer 
expellent as the cockroaches comprise a truth which no one even utters. (3)

The mind of the Lacanian psychotic subject is divided into shifting layers keen to find unity at the early hours of the day. Mariia Haatanen refers to those lines in "The Effects of Medicalization, Medical Disorder on the Subjective Experience of the Self in Sarah Kane's 4.48 Psychosis" as she states that they show that the subject's consciousness is "formed out of fragments" and the shifting floor "gives a clear impression of a mind that is unstable, a mind without permanent foundation" which reflects "the fragmentary nature of her mind" (76-77).

The decentered fragmented Lacanian subject is aware of its discrepancy which is driving it to further disintegration and threatening its disappearance as the protagonist in Kane's 4.48 Psychosis cries out in despair: "I need to become who I already am and will bellow forever at this incongruity which has committed me to hell" (8). The postmodern subject has lost its previous construct which has been dismantled to unassembled shreds and it is toiling to contain its dispersed particles by enclosing its ruptured outlines; "Grid yourselves: for ye shall be broken in pieces" (20). It is in the mind where disseverment takes place and the subject is invaded by dissonance as threads of thoughts diverge and a clash occurs between the discourse constituent signs:

my thought walks away with a killing smile

leaving discordant anxiety

which roars in my soul (12)

Discord hit the consistency of thoughts and the Lacanian subject growls in agony as Kane's character screams out with bold eagerness to contain its dispersed ruptured mind particles: "Grid yourselves" (20). Lacan, in The Psychoses: The Seminar of Jacques Lacan, states:

The myth of unity of the personality, the myth of synthesis, of superior and inferior functions, confusion about automatism, all these types of organization of the objective field constantly reveal cracks, tears and rents, negation of the facts, and misrecognition of the most immediate experience. (Loc 315) 
Having a whole unified self has become an illusion according to Lacan's theories as the fractures have permeated structures.

Lacan asserts that a rupture in the symbolic world of signification is detected in holes found in the psychotic discourse. In the Encyclopedia of Lacanian Psychoanalysis and under the title of "Jacques Lacan: The Subject of the Unconscious", the unconscious is described as a "gap" or "rupture". According to Lacan as stated in the encyclopedia, the unconscious must "be apprehended in its experience of rupture, between perception and consciousness":

The unconscious manifests itself at those moments in which processes beyond conscious thought disrupt speech, points when language fails. Lacan defines the unconscious in terms of "impediment", "failure" and "splitting". The unconscious is precisely this gap or rupture in the symbolic chain.

Rupture of chains of mind occurs when the unconscious imposes itself upon speech causing its hindrance, cessation and cleavage. Lacan affirms that a fissured reality spurs the imagination of the psychotic to stitch its hole; "[...] a hole, a fault, a point of rupture, in the structure of the external world finds itself patched over by psychotic fantasy" (Loc 1151).

Postmodernism has shoved language to the foreground of psychoanalysis fully invading the territories of psychotics. Lacan embraces his belief that "the unconscious is a language" as he affirms its significance to the subject when he says; "Not only does discourse invade him, not only is it a parasite in him, but he is dependent on its presence" (Loc 3578). It is language that inhabits and speaks through the subject as Lacan affirms that he spoke of "language insofar as it's inhabited by the subject who to a greater or lesser extent speaks out in language with all his being, that is, in part unknowingly" (Loc 5400) and he adds: 
How can one fail to see in the phenomenology of psychosis that everything from beginning to end stems from a particular relationship between the subject and this language that has suddenly been thrust into the foreground, that speaks all by itself, out loud, in its noise and furor, as well as in its neutrality? If the neurotic inhabits language, the psychotic is inhabited by language. (Loc 5400 - 5409)

There has always been an interconnected affiliation between subject and language and that has gradually shoved its path to the front gaining full dominance over discourse.

The unconscious has become the commanding sovereign in the rebellious reign of the self in accordance with Lacan's theories. It is in its cabinets where signs are kept, suppressed and invoked as Lacan, in The Psychoses: The Seminar of Jacques Lacan, questions;

What part in the subject talks? Analysis says it's the unconscious. Naturally, for this question to make sense you have to have already admitted that the unconscious is something that speaks within the subject, beyond the subject, and even when the subject does not know it, and that says more about him than he believes. (Loc 1044-1057)

Lacan stresses the point that the "the unconscious is a language" and that "it's classically said that in psychosis the unconscious is at the surface, conscious." Moreover, language is "its being articulated doesn't imply its recognition though" and "the psychotic subject is ignorant of the language he speaks" (Loc 393). Carolina SanchezPalencia Carazo in "4.48 Psychosis: Sarah Kane's bewildered fragments" affirms that the play does not have a "subject in the conventional sense" and consequently language does not exist in the "conventional sense." She states, "in this text there are neither characters nor indications for actors or setting, but only [...] unidentified voices" (2-3). Similarly, Karoline Gritzner in Adorno and Modern Theatre: The Drama of the Damaged Self in Bond Rudkin, Barker and Kane states that 
the play [4.48 Psychosis] presents an added challenge due to the fact that it does not contain any specified characters - the play for this reason resembles a dramatic poem rather than a play, even though there are moments of dialogue. However, the dialogue as much as everything else in the play can be envisaged as taking place in the consciousness (or indeed the unconscious mind) of the speaker. (158)

The indefinable fleeting facet of 4.48 Psychosis is mirrored in its deprivation of definite structure.

Fragmentation of text in 4.48 Psychosis reflects the rupture of the unconscious that speaks through its subjects. Sarah Kane's 4.48 Psychosis erupts with variations of discourse scraps represented in dialogues, poetry, numbers and medical prescriptions. Gritzner states that "Kane resists the synthesis of body and mind, or reason and consciousness, even though her work is still imbued by a utopian wish for such synthesis" and that "4.48 Psychosis is characterized by an increasingly poetic (musical) and minimalist use of language and further fragmentations of dramatic form" (152 - 155). Similarly, Martina Chramosilová in Beyond the Suicidal Despair: An Analysis of Sarah Kane's 4.48 Psychosis, states that

The fragmentation of the text corroborates the fragmentation of the patient's mind as "[her] mind is the subject of these bewildered fragments." The words are scattered on the page as if they were scattered on the patient's mind, but there still is some order in it, even if it may seem chaotic at first. The individual scenes are divided by a series of dashes " - - - ", dialogues take frequent, almost cyclical turns with monologic and poetic passages. Kane" s use of gaps and silences is equally as important as other features of the text. (23)

The ruptured textual unconscious of subjects indicates identities which are obscure and their presence is doubted.

The mind of the psychotic character in Kane's play is constituted of ruptured chains of language as we are deafened with the character's verbalized wails while staggering over the fiery cracks and 
pits of the mind; "Burning in a hot tunnel of dismay, my humiliation complete as I shake without reason and stumble over words and have nothing to say about my 'illness' which anyway amounts only to knowing that there's no point in anything because I'm going to die" (5-6). This dark abyss in the mind is further accentuated when the subject howls;

I will drown in dysphoria

in the cold black pond of my self

the pit of my immaterial mind (8)

The sign submerged in depression is related to a disruption in chains of signifiers and gaps upon which it blunders and collapses.

It is inside the shifting fissured layers of the mind where all actions take place; the source of ailment is the brain with all its texts rupturing and collapsing as the psychotic character cries; "derailed/deranged/deform/ free form/ obscure to the point" (16). The subject goes off the sanity rails of ordered chains of signs into distracted irrational zones of scattered signs. Such displacement leads to unhinged subjects disfigured in structure and regular constructs that their appearance has become opaque to vision. The ruptured mind of the psychotic breeds the nucleus of all the depression where folds are multiplying indicating an endless dissection and infinite proliferation of signifiers:

They will love me for that which destroys me

the sword in my dreams

the dust of my thoughts

the sickness that breeds in the folds of my mind. (8)

The mind is both the place where the subject as a sign is born and where it is terminated and destroyed. Kane's subject cries in despair; "To my mind that's betrayal. And my mind is the subject of these bewildered fragments" and that deteriorates into further disintegration; "I'm tired of life and my mind wants to die" (6-7). The mind has become the main domain that stands for the subject and the death of signifiers reflects its own death. The cessation of the "name" 
stands for the subject dissolution; "When I'm an old lady living in the street forgetting my name she'll still be dead, she'll still be dead, she'll still be dead" (12-13). The Lacanian subject has become a hollow sign in language with not even a proper name or a title appointed to it as the character admits that he/she is "deadlocked", "not here and never been there", and It is evident in the absence of names in the plays which are substituted by dashes. Gaps are markedly observed at the early hours of the day with the first spark of light as the subject announces:

\section{Hatch opens}

Stark light

the rupture begins

As the play comes to its end, we see gaps among signifiers increasing and enlarging with pages left blank indicating the threat of disappearance after becoming disseminated as the subject cries; "Watch me vanish" (33).

Lacan compares the interwoven structure of the unconscious to language loops of ever circulating signs. He affirms in The Psychoses: The Seminar of Jacques Lacan: "The unconscious is fundamentally structured, woven, chained, meshed, by language. And not only does the signifier play as big a role there as the signified does, but it plays the fundamental role. In fact, what characterizes language is the system of signifiers as such" (Loc 2691-2695). He, also, affirms that the signifiers are bound in signifying chains, which form the unconscious and "responsible for generating signification at the conscious level." Chiesa in Subjectivity and Otherness: A Philosophical Reading of Lacan writes that the unconscious which structures the subject is made up of signifiers which "transcend the conscious dimension of the signified" and that "signifiers are linked in many synchronic unconscious signifying chains, which ultimately are the unconscious" (49).

The subject is so closely attached to the signifier that it has become its synonym. Chiesa, in Subjectivity and Otherness: A Philosophical Reading of Lacan, asserts that Lacan's contemplation of the signifier is perpetually intermeshing and interfacing the concept of 
"subject" (49). As the signified was emptied of meaning and became a void space, the subject has become the equivalent of the signifier. Lacan affirms that the signifier takes the frontier of the subject as it controls its entire being; its actions, behavior and even its fate are all dictated by the input of signifiers. The subject becomes a synonym of signifier as he states in The Psychoses: The Seminar of Jacques Lacan one "gets completely inside himself, with the signifier, it's he who becomes the signifier. His real, or his imaginary, enters into the discourse" (Loc 3476). Lacan clearly states in Ecrits that:

This passion of the signifier thus becomes a new dimension of the human condition in that it is not only man who speaks, but in man and through man that it speaks; in that his nature becomes woven by effects in which the structure of the language of which he becomes the material can be refound; and in that the relation of speech thus resonates in him, beyond anything that could have been conceived of by the psychology of ideas. (689)

The subject is besieged by the signifier, which coerces itself through discourse disrupting its flow. The subject and signifier collapse to become the same unit as the former is deeply interweaved into the fabric of language.

The subject emerges as a floating empty signifier lacking a sense of form, identity or gender. In Sarah Kane's 4.48 Psychosis, we are perplexed by a text uttered by a hollow unidentifiable signifier which wavers between male and female, singular and plural and present and absent. Audiences struggle to grasp his/her form or get hold of his/her identity that has been diminished to a dash or a trace lacking names or labels and endangered to fade away and disappear. Susan Blattes in "Is the Concept of 'Character' Still Relevant in Contemporary Drama?" states that in Kane's 4.48 Psychosis "the existence of 'character' is perhaps the most problematic" of all her plays and its text "contains little if any indication as to how the text might be distributed between speakers" (78). She proceeds affirming that Kane's play has an indirect oblique approach "by breaking with conventional ideas of coherence" as "it becomes impossible to 
connect speakers to characters" and "we cannot identify precise characters in a coherent dramatic universe" (79).

Similarly Mariia Haatanen in "The Effects of Medicalization, Medical Practices, and Mental Disorder on the Subjective Experience of the Self in Sarah Kane's 4.48 Psychosis" states that the play "is distinctly postmodern in style and content with its fragmented and ambiguous nature" and it is "the shortest and the most fragmented of Kane's plays." She adds that characters in 4.48 Psychosis "have no names at all, and there are no markings to tell which character is speaking each time. [...]. There is no evidence as to how many characters or speakers there are supposed to be in the play, and whether all the voices belong to different characters" (3-4). Hence, the Lacanian character/characters in Sarah Kane's 4-48 Psychosis emerge(s) as adrift divided signifiers on the verge of disappearance. In seminar thirteen published in The Seminar of Jacques Lacan: Book $X V$ : The Psychoanalytic Act, Lacan affirms that the subject dwells in the unconscious stating that "to go into the field of the unconscious is properly to find oneself at the level of what can be best defined as language-effect" and "the subject, because of the effect of the signifier, is only established as divided" (XIII 3- XIII 4). Jozef Corveleyn and Paul Moyaert in Psychosis: Phenomenological and Psychoanalytical Approaches state:

The only thing that remains and is being cathected are words that have become empty shells. Words that no longer refer to anything have become the last remainders of connection with a reality that makes itself known as an emptiness. In this empty world of words the schizophrenic maintains himself a subject without a body, as a subject that has become a pure, meaningless signifier. (56)

The empty subject manifested as a hollow signifier is drained of all words as he/she expresses: "How can I speak again?" and when she wanders among void silent others in "a room of expressionless faces staring blankly" at her of pain, she retreats with despair. Kane's afloat empty signifiers are on the brink of dispersal and dissolution as stated in the play: "the only thing that's permanent is destruction" followed by "we're all going to disappear"(29). The trace is the only thing that 
remains of the subject and it is more enduring than the subject him/herself.

As the Lacanian subject is decentered in a similar manner as the signifier; it has been cut loose and given endless grounds to roam and float. Lacan, in The Psychoses: The Seminar of Jacques Lacan, refers to the aimlessly floating nature of signifiers with no tethering anchor: "The signifier may extend over many of the elements within the domain of the sign. But the signifier is a sign that doesn't refer to any object [...]. It, too, is the sign of an absence" (Loc 3688). Moreover, the broken unity between the signifier and signified is paralleled to the insufficient subject as a sign in language. Dany Nobus in "Lacan's Science of the Subject: Between Linguistics and Topology" points out that Lacan was influenced by the structuralists' theories of dismantling the "unity of the linguistic sign" and the substitution of "inadequation" for "equivalence" and "non-fit" for adequacy. He also affirms that "Until the end of his intellectual career, Lacan did not budge an inch on the supremacy of the signifier and the 'inadequation' of its relationship with the signified" (56). Nobus draws our attention to Lacan's beliefs that the "floating signifier" and the "flowing signified" tend to leap over borders manifested in the bar standing in between both. Nobus highlights Lacan's theory that "No signifier ever 'fits' a signified perfectly, human beings doing their utmost to distribute the available signifiers across the board of signifieds without ever creating a perfect match" (55). Nobus affirms:

The subject should not be understood here as the unified, selfconscious being or the integrated personality so dear to many a psychologist, but as the subject of the unconscious - a subject that does not function as the center of human thought and action, but which inhabits the mind as an elusive agency, controlling yet uncontrollable. (61)

The decentered Lacanian subject does not belong to a stable coherent conscious anymore as it has shifted grounds to the fragmented unconscious; the subject as an emancipated unbound signifier is given free rein to roam unconscious and emerges in speech. 
The mind signifying chains of the Lacanian subjects snap and signs are ruptured into signifiers and signifieds aimlessly drifting apart and meanings are gone absent. Karoline Gritzner in "Sarah Kane or how to "scrape a life out of the ruins"" published in Adorno and Modern Theatre: The Drama of the Damaged Self in Bond, Rudkin, Barker and Kane states that in Kane's play:

Expression, whether as articulation, verbalisation or gesture, becomes a physical manifestation, a structure devoid of content. And the point at which form becomes an abstraction, a pure form, is also the point at which the subject approaches death. The dialectic between the signifier and the signified in the chain of signification (language), translated into the dialectic of presence and absence in the psyche, finds its aesthetic articulation in the paradoxical formlessness of a text. (160)

The discourse of the subject has lost its structure whence the clasps holding signifiers and signifieds are untied. When the subject, which is made of fissured signifying chains, experiences such rupture, it undergoes displacement and decentering. Gritzner proceeds that "this consciousness of connection and relation (of being connected to the world, to others, etc.) is lacking in the speaker, which results in her experience of herself as a floating, dislocated signifier" (226).

The Lacanian subject in Sarah Kane's 4.48 Psychosis stumbles with grievances in securing utterances in their discourse. We overhear his/ her sufferings as she cries in despair: "my humiliation complete as I shake without reason and stumble over words and have nothing to say about my 'illness' which anyway amounts only to knowing that there's no point in anything because I'm going to die" (6). The subject in the play is striving to pin a meaning for the word "metaphor" and "simile" as he/she states; "It's not a metaphor, it's a simile, but even if it were, the defining feature of a metaphor is that it's real" (7). Her attempts are met by failure due to the hovering and slipping nature of chains of signifiers and signified; she shifted the ground to another signifier which is "age" that he/she fails to pin to a content or a certain number:

(A long silence.) 
-You are not eighty years old.

(Silence.)

Are you?

(A silence.)

Are you?

(A silence.)

Or are you?

(A long silence.) (7).

The encountering of small and big gaps in signifying chains is reflected in "silences" abruptly fixating discourse hindering its spontaneity. Jozef Corveleyn and Paul Moyaert in Psychosis: Phenomenological and Psychoanalytical Approaches write that the "schizophrenic word associations [...] are not over-determined in their meaning but are empty of meaning" and "the free play of words no longer clings to object-representations [...], it no longer connects to the personal life-history of the subject that speaks and it has lost its anchor in the body. Words glide over everything and hang in empty space" (56). The signifiers are disconnected from signifieds as Lacan pointed out in The Psychoses: The Seminar of Jacques Lacan that "The signifier is to be thought of initially as distinct from meaning. It is characterized by not in itself possessing a literal meaning" (Loc 4365). He added that there is "dissolution of the link between intentional meaning and the apparatus of signifiers" (Loc 4901). It is the signifier that gives existence to the subject as Lacan stated in, The Psychoses: The Seminar of Jacques Lacan, “The signifier doesn't just provide an envelope, a receptacle for meaning. It polarizes it, structures it, and brings it into existence. Without an exact knowledge of the order proper to the signifier and its properties, it's impossible to understand anything whatsoever" (Loc 5628). The scrambled vague words that appear in the postmodern psychotic subject start with the dent created by an absent signifier, "The-Name-of-the-Father."

The sliding disposition of the signifiers and the signifieds is due to the hole or rupture in the signifying chains created by the missing paternal signifier called "the-Name-of-the-Father" which is 
considered the "linguistic function of authority" and it is an expression that first appeared in Lacan's work according to the Encyclopedia of Lacanian Psychoanalysis. It can either refer to the "legislative and prohibitive function" of the "symbolic father" or play the role of a fundamental signifier which "permits signification to proceed normally." The Name-of-the-Father in this case "confers identity on human subjects (by situating them in a lineage and the symbolic order)." Chiesa in, Subjectivity and Otherness: A Philosophical Reading of Lacan, tracks the Name-of-the-Father to earlier stages of childhood and compares it to "Law"; "the Law needs to be embodied in a concrete figure for the child to be able to access it [. . .] this very embodiment can never be complete" (81). Bruce Fink in A Clinical Introduction to Lacanian Psychoanalysis: Theory and Technique states that according to Lacan the father is the "button tie" or "anchoring point" or "quilting point" that is established between language and meaning or between signifier and signified. He resumes that its function is to create "a foundational, unshakable meaning" and it is "this one stitch that allows someone to assimilate the structure of language" without which "everything comes undone" (93-94).

Psychosis is triggered when the Name-of-the-Father, the master signifier, representing the Law upon which the entire culture and language signifying network rely, goes missing. It governs signifiers in their operation and effects and hence it structures our lives and stabilizes our self-images and our relationships. Similarly, Yannis Grammatopoulos, in Above the Ground and Beneath the Clouds: Schizophrenia in Lacanian Psychoanalysis, affirms that "not all signifiers are of equal status" and "there is one signifier that is considered responsible for the 'normative' articulation of signifiers that the subject depends on" (51-51)." He proceeds that "this signifier is called the "Name-of-the-Father"" and "whether the subject becomes psychotic or not will depend on its function or dysfunction" (52). Grammatopoulos asserts that the paternal "signifier's intervention makes language less threatening, since meaning is conditioned by signifying rules. It does not flow. It cannot appear anywhere. The imaginary axis is thus regulated by the symbolic" (53). He states that psychosis arises when the psychotic lacks the 
"regulating agent upon the field of signifiers that come from the Other, there was not Other of the Other" (54).

It is the foreclosure of "the word" that provokes psychosis to be vented through language as manifested in the Sarah Kane's psychotic character's words; "Just a word on a page and there is the drama" (9). According to Lacan, the Other of the Other is called God as he states in The Sinthome: The Seminar of Jacques Lacan: Book XXIII; "the whole necessity of the human race being that there should be an Other of the Other. This is what is generally called God" (49). The psychotic character of Sarah Kane's 4.48 Psychosis is being confronted with horrific scenes of injustices, cruelty and savagery executed by humanity and manifested in the subjects themselves; "I killed the Kurds, I bombed the Arabs, I fucked small children while they begged for mercy, the killing fields are mine," she/he starts questioning the Law behind such disturbing scenes and the name of God in relation to all the violent words gushing through speech. Andreja Zevnik, in Lacan, Deleuze and World Politics: Rethinking the Ontology of the Political Subject, states that society is built on laws which emanate from "the father" who crafted humanity at large:

The two totemic laws then build the foundations of modern society, and the figure emerging from these two laws -the father- becomes central to life in society. This is a basic law, which created humanity and imposes rules of language and legality on the subject. It follows that the subject by becoming the subject of language internalizes the rules of society, these rules frame the subject's desire and perceptions of what is right or wrong, acceptable or prohibited. (29)

It is "the father" who represents God in accordance with Lacan's theory and His name is weaved within the symbolic as the begetter of laws. Zevnick affirms; "Lacan claimed, the idea of the father, its name, substitutes the real authority of God in a period when God is dead. Lacan does not detach sources of law from the Symbolic." He adds that every legitimate power "rests on the symbol or a name, and each signifying articulation (including the articulation of the subject) can not occur outside the legislative function." Hence, the subject manifested in the "I" relies on God to secure its place of 
existence; "This is a way in which being gets instituted as the alleged 'autonomous' subject of law - the authority of law guarantees the existence of the 'I'" (29-30). Hence the presence of Kane's psychotic subject is shaken by the controversial presence of the Name-of-theFather.

The rupture of the outlines of the structures occurs as an outcome of the hole in the signifying mind chains of the subject where the Name-of-the-Father goes missing resulting in subject dispersion and disappearance. The decentered subject emerges from the absence of God who ties the signifying chains and gives the subject its existence. God's words as mentioned in the BibleGateway; "Associate yourselves, $\mathrm{O}$ ye people, and ye shall be broken in pieces; and give ear, all ye of far countries: gird yourselves, and ye shall be broken in pieces" resonate in Kane's words "Grid yourselves:/for ye shall be broken in pieces/it shall come to pass." Zevnik asserts that "if God does not exist, everything is prohibited" and "if there is no framework to which prohibition applies or no limits to the law, then the subject, [...], no longer knows the limits and the conditions of its existence. Instead of being completely free, eradication of limits leads a subject to lose its compass. Instead of experiencing absolute freedom the subject no longer knows what to do" (30). The clarity of God's presence in Kane's 4.48 Psychosis diminishes and declines to mere visions which are fading away; "I saw visions of God/and it shall come to pass" (19) leading the postmodern subject to "despair: and "anguish" as humanity is "driven to darkness" (20).

The absence of God has driven the decentered subject to insanity and dispersion and hence it beckons humanity to re-establish the center where God resides; "Sanity is found in the mountain of the Lord's house on the/ horizon of the soul that eternally recedes" (20). Lacan in Ecrits: A Selection, interlinks the foreclosure of the Nameof-the-Father to psychosis as he affirms; "It is an accident of this register and in what takes place in it, namely the foreclosure of the Name-of-the-Father in the place of the Other and in the failure of the paternal metaphor, that I designate the defect that gives psychosis its essential condition, and the structure that separates it from neurosis" (215). 
The foreclosure of the Name-of the Father is realized by the subject when confronted by an inadequate relationship with an "other" which is clearly evident in the character's frustrated insufficient affiliation with the doctor in Kane's 4.48 Psychosis. Alphonse De Waelhens and Wilfried Ver Eecke in Phenomenology and Lacan on Schizophrenia: After the Decade of the Brain state: "the foreclosure of the paternal signifier, rejected from the unconscious, which makes psychosis possible and virtually constitutes it, this psychosis will not, however, become manifest or active until the time when this signifier reappears in hallucinatory form in the real" (220). De Waelhens and Ver Eecke resume saying that subjects will remain virtual psychotics till they encounter in the real the hallucinated signifier related to paternal signifier emerging via "a real father", called by Lacan "A-father", who is not necessarily the father of the subject and might stand for "intellectual prestige", "devotion" or "the old and affectionate friendship" (221). Lacan in Psychoses: Seminar of Jacques Lacan asks; "Where does the difference between someone who is psychotic and someone who isn't come from? It comes from the fact that for the psychotic as love relation that abolishes him as a subject is possible insofar as it allows a radical heterogeneity of the Other. But this love is also a dead love." (Loc 5481). Hence, Kane's subject encountered the signifiers of the other with their full unbearable impact which prodded him to light upon the Other. The subject sees in the lover the father "What am I like?/just like my father" followed by "Hatch opens/ Stark light/ the rupture begins" (29). Sarah Kane's psychotic subject is wrecked with frustration in the deceit of the other and false affections as we hear her/his outcry of pain;

I want to scream for you, the only doctor who ever touched me voluntarily, who looked me in the eye, who laughed at my gallows humor [...], who lied and said it was nice to see me. Who lied. And said it was nice to see me. I trusted you, I loved you, and it's not losing you that hurts me, but your bare-faced fucking falsehoods that masquerade as medical notes. (6) 
She/he adds "To my mind that's betrayal. And my mind is the subject of these bewildered fragments," "nothing can extinguish my anger," or "restore my faith" (6). It is the shock of that dishonest fabricated love that triggered psychosis in the Kane's character by fragmenting her mind chains and foreclosing the Name-of-the-Father represented in "faith".

The character's ailment in a disappointed other who betrayed her love is further stated; "Sometimes I turn around and catch the smell of you and I cannot go on I can not fucking go on without expressing this terrible so fucking awful physical aching fucking longing I have for you"(9). Her love is not returned as she/he questions; "And I can not believe that I can feel this for you and you feel nothing. Do you feel nothing?" (9) and adds; "Fuck you for rejecting me by never being there, [...] fuck you for bleeding the fucking love and life out of me" (10). Lorens Holm in "Space and its Assembled Subjects: The Neurotic, the Psychotic and the Pervert" interconnects the fracture between the subjects with their love objects with the foreclosure of the Name-of-the-Father as he states; "In the text of Lacan, this authority is signified by what he calls the name-ofthe-father, the signifier of the father in a semiotic event that has the structure of metaphor [...], the signifier of authority replaces the real love of the mother in the unconscious of the subject." He adds; "The psychotic subject suffers a semiotic failure he is unable to summon the signifier of the father, the authority of which guarantees the subject's power and efficacy in the symbolic world because it never replaced the real love of the mother" (44).

Once the foreclosure of the paternal signifier occurs, language impairments take place indicated in defects in signifying chains as interruptions, repetition, fixation, poetic language and neologism. Bruce Fink in A Clinical Introduction to Lacanian Psychoanalysis: Theory and Technique states:

In psychosis, the paternal metaphor fails to function and the structure of language [...] is not assimilated. When language operates without that structure, other disturbances may appear as well. For example the voices the psychotic hears often speak in interrupted phrases or sentences that break off just 
before the most important term is uttered, and the patient feels obliged to supply the missing part of the sentence. (94)

The malfunction of psychotic language is reflected in ruptures and vents evident in abrupt interruptions in speech. Silences, pauses and broken fragments in the psychotic speech are clearly obvious in Kane's 4.48 Psychosis in which characters struggle to fill in the void in the fissured signifying chains of their disturbed minds.

Interruptions in Sarah Kane's 4.48 Psychosis prevail throughout the text with silences and pauses that vary in duration. The play starts with "a very long silence" followed by a "long silence" then "silence" as clear in:

\section{(A very long silence.)}

But you have friends.

(A long silence.)

You have a lot of friends.

What do you offer your friends to make them so supportive?

(A long silence.)

What do you offer?

(Silence.) (3)

Furthermore as apparent from the above text, we encounter other means of interruptions like a middle fragment torn from a sentence and an abrupt variation of declarative and interrogative sentences. With the psychotic character, some signifiers show persistence and shove their way to the surface of speech as clear when "shame shame shame" that breaks the signifying chains of the Lacanian ruptured mind (6). Anna Ovaska in "Sarah Kane's World of Depression: The Emergence and Experience of Mental Illness in 4.48 Psychosis" connects the gaps to the mental deteriorating condition of the subject as she says; "the use of silences and gaps create changes in mood throughout the text, ranging from anger to resignation. In the final scene, the gaps grow wider and are more and more tied to the disappearance of subjectivity and approaching death." She, also, sheds light that the repetitive usage of dark words as dark, nightmare, 
sad, hopeless, depressed, death, suicide, cry, tears, bitter, grief and others are Kane's cockroaches that populated the play" and they indicate the desperation and depression of a psychotic mind (8-10). Ovaska links the repetition prevailing mode of the play to Lacan's theories as she writes; "For Lacan, repetition has a major significance in a psychosis. It is given as an impulse. The psychotic tends to repeat acts and words constantly, producing a disorganization of the mind. Every time something is repeated, it signifies something different and it can lead to a different context" (11).

Cessation of speech is repetitively detected throughout the play as in the presence of full stops suggesting brief momentary intermissions as in; "Please... / Money ... / Wife..." (18) or longer ones reflected in the five "silences" observed in one page standing for gaps of absent signifieds:

But now you've touched me somewhere so fucking deep I can't believe and I can't be that for you. Because I can't find you.

(Silence.)

What does she look like?

And how will I know here when I see her?

She'll die, she'll die, she'll only fucking die.

(Silence.)

Do you think it's possible for a person to be born in the wrong body?

(Silence.) (10)

The interruptions indicated in the above "silences" are equivalent to the absence of subject signifiers that can not be pinned to specific certain identities. The slippage of signifieds below signifiers is reflected in such silences as marked when the character was asked about the reason of cutting her arm:

Did it relieve the tension?

No. 
Did it give you relief?

(Silence.)

Did it give you relief?

No.

I don't understand why you did that.

Then ask.

Did it relieve the tension?

(A long silence.) (11)

The character is struggling to locate the signified by pinpointing the meaning behind cutting her arm. Anna Ovaska in "Sarah Kane's World of Depression: The Emergence and Experience of Mental Illness in 4.48 Psychosis" states that "silence" is repeated 38 times in the play and that it "becomes a fragment" until the end when it is followed by the capitalized word; "Nothing" indicating the "land of nothing" where the character vanishes on an empty page. She then adds that "silence" is part of a dialogue that never comes to cessation and that proves the endless flowing chains of signifiers (17).

Variation between repetition and fixation is another aspect that reflects the ruptured chains of mind of the psychotic. Repetition in Kane's 4.48 Psychosis is indicated in successive synonymic words as in "True Right Correct / Anyone or anybody / Each every all" (16) or in replicated signifiers as evident in "No hope" which is repeated six times, "How do I stop?" that is repeated eight times and "I REFUSE" and "she'll still be dead" which are both repeated three times. Moreover, there is a repetition of same prefix as the subject strives to find the correct root of the signifier as clear in "unpleasant / unacceptable / uninspiring", "irrelevant / irreverent / irreligious", "irrational/irreducible/ irredeemable" and "derailed / deranged / deform" (15-16.). Lacan in The Psychoses: The Seminar of Jacques Lacan states; "Psychosis not only depends on what appears at the level of meanings, of their proliferation, of their labyrinth, in which the subject is supposedly lost or, even, arrested at a fixation, but also that essentially it stems from something that is situated at the level of the subject's relations with the signifier" (Loc 4356 ). Moreover, 
Gabriel Nicolas Larenas Rosa in "Language of a Broken Mind: Suicidal Poetic Techniques and Dramatic Dialogue in 4.48 Psychosis" states; "Repetition seems to be the main strategy for Sarah Kane to make the dialogue work. For Lacan, repetition has a major significance in a psychosis. It is given as an impulse. The psychotic tends to repeat acts and words constantly, producing a disorganization of the mind" (11).

Repetition serves as means in the detouring nomadic nature of the Lacanian Subject. Cermak, Chrz and Zabrodska in "4.48 Psychosis' as a Suicide Note of Sarah Kane?" Published in Narrative and Memory interconnects the repetition of words and sentences in the play to a cyclic movement as he writes:

The movement is fragmentary, similar to rotation in a carousel; certain sentences appear again and again in a form of a refrain. If we want to give a true picture of the play configuration through the category of chronotope, then the crucial place would be a lunatic asylum, and the crucial moment would be 4.48 hours, and the crucial movement would be a rotating carousel. (112)

The cyclic movement indicates the fragmentary mind of Kane's subject with words indefinitely multiplying in the mind like cockroaches in the dark. Repetition stands as the chord that holds the play together without which the play would be a poetic collection.

Alternation between prolonged extended fluid and short irrelative discourse is indicated throughout the play as clearly evident in "a consolidated consciousness resides in a darkened banqueting hall near the ceiling of a mind whose floor shifts as ten thousand cockroaches when a shaft of light enters as all thoughts unite in an instant of accord body no longer expellent as the cockroaches comprise a truth which no one ever utters" which is directly followed by "I had a night in which everything was revealed to me" then a question marking the silence of speech; "How can I speak again?" (3). Similarly a lengthened sentence marked with prolixity; "But drinking bitter black coffee I catch that medicinal smell in a cloud of ancient tobacco and something touched me in that still place and a wound form two years ago opens like a cadaver and a long buried shame 
roars its foul decaying grief" is interrupted by a persistent short one; "A room of expressionless faces staring blankly at my pain, so devoid of meaning there must be evil intent" (5). The character groans with repetitive prolonged lamentation; "I can't eat"/'I can't sleep"/'I can't think"/ "I can't write"/ "I cannot write"/ "I cannot love" fixated by "My brother is dying, my lover is dying, I am killing them both/ I am charging towards my death" (4). The insistent irrelative sentence reflects the delusions of the psychotic mind that lingers on the mind.

Such variation between repetition and fixation is also evident in a whole page that starts with the word "I can't" fixated with the persistent signifier "death" that forces itself on the psychotic speech driving the subject to end its existence in language. The signifier, "death", hinders and suspends the superfluousness of speech as the unforeseen encounter of death is indicated in: "I have resigned myself to death this year" (5), "I just hope to God that death is the fucking end" (7), "I beg you to save me from this madness that eats me a sub-intentional death"(18), and "I'm tired of life and my mind wants to die" (7), "The vital need for which I would die" (13) and "a tab of death squeezing my heart" (18). Similarly the signifier "roaches" frequently imposes itself to interrupt the temporally spontaneity of discourse;

a dismal whistle that is the cry of heartbreak around the hellish bowl at the ceiling of my mind

a blanket of roaches (19)

Likewise, the speech about God is interrupted by "roaches"; "Fear God / and his wicked convocation / A scall on my skin, a seethe in my heart / a blanket of roaches on which we dance / this infernal state of siege" (20). Karoline Gritzner in Adorno and Modern Theatre: The Drama of the Damaged Self in Bond, Rudkin, Barker and Kane, highlights such variations in Kane's 4.48 Psychosis as she writes that the psychotic who is "inhabited" and "possessed" by language "finds expression in the fragmentary dramatic form of the play, with its repetitions of phrases, ellipses and silences, verbal explosions and ruptures" (231). 
Text fragmentation of Kane's 4.48 Psychosis indicated in the multiplicity of style reflects a ruptured mind. The text is brimming with scattered signifiers indicated in words standing by themselves as "Ask / Me /Why", "Breakdown" and a whole page with words repeated and disseminated like scattered beads; "slash wring punch burn flicker dab float dab" (22). In the same manner we find interrupted scrambled numbers, patient symptoms, medical prescriptions and reports. We, also, encounter unaligned fragments and sentences with no uniformity shown in variations of long and short sentences given in poetic and prose styles. Ken Urban in "An Ethics of Catastrophe: The Theatre of Sarah Kane" draws attention to the variations in text style of the play which reflects the fragmentary mind of the character:

This piece is the equivalent of a textual collage; there is a citational quality to the language, as if it were culled from disparate sources. The play has passages of poetic language juxtaposed with moments of naturalistic dialogue, intercut with lists of numbers of unknown significance, all placed in specific ways on the page to indicate possible delivery and meaning. Yet, the play's multiplicity also creates the uncanny sensation that the text is deeply monologic, the product of a singular, albeit divided, self.

The variations and multiplicity of styles reflect the divided subject in Kane's play. However, the play is considered by many critics as "dramatic-poetic writing" with blank verse dominating its structure. Gabriel Nicolas Larenas Rosa in "Language of a Broken Mind: Suicidal Poetic Techniques and Dramatic Dialogue in 4.48 Psychosis" states that Kane's "dramatic-poetic writing is to achieve a dense psychological, suicidal, atmosphere" and its predominant free verse style is intended to "rouse emotions violently" through dark imagery (1-14). Lacan in The Psychoses: The Seminar of Jacques Lacan claims that "There is poetry whenever writing introduces us to a world other than our own and also makes it our own, making present a being, a certain fundamental relationship" (Loc 1808).

The use of neologisms is another indication of the ruptured chains of the psychotic mind as signifiers are set free, crack against each other and swarm in a pressing tendency to meld and integrate. 
The psychotic mind is a microcosm of the postmodern subject itself characterized by hybridity and assimilation. Lacan defines neologism in The Psychoses: The Seminar of Jacques Lacan as a clustered form of signifiers which emerge with intensity and pressing insistence: "It's language in which certain words take on a special emphasis, a density that sometimes manifests itself in the very form of the signifier, giving it this frankly neologistic character that is so striking in the creations of paranoia" (Loc 852). The gender and identity of the character in Kane's 4.48 Psychosis remain undetermined and hence neologism emerges as evident when he/she desperately says; "the broken hermaphrodite who trusted hermself alone finds the room in reality teeming and begs never to wake from the nightmare" (3). The cracked broken postmodern subject has become a deformed hybrid manifested in "hermaphrodite" which according to Merriam Webster Dictionary means "an animal or plant having both male and female reproductive tissue or organs." This half-breed does not have a clear gender distinction and thus we are confronted with a neologistic term "hermself" in which borders disappear and an inclination to have an incorporated neutral gender surfaces.

Fragmentation of the postmodern Lacanian subject gives rise to alienation mounting to aggressiveness and violence. Mind rupture commences with a fissure created in the signifying chains initiating a vicious inner strife in desperate need to close such vents and find unity. Lacan in The Psychosis: The Seminar of Jacques Lacan states; "This dialectic of the unconscious always implies struggle" (Loc 1020) and hence the depressed frustrated character of Kane intensely shows herself throughout the play driving her to isolation and desperation as she states:

I am sad

improve

I feel that the future is hopeless and that things cannot

I am bored and dissatisfied with everything

I am a complete failure as a person

I am guilty, I am being punished

I would like to kill myself (4) 
Feelings of alienation and abandonment felt by Kane's character are interconnected with bitterness of betrayal which triggered her anger and aggresivity.

The outbreak of psychosis is interdependent with the realization of the subject's own horrific fragmentation which is furthered upon recognizing that the Other who projects a sense of unity on the subject is fissured. The inconsistence and division of both the subject and Other feed into each other adding to the vicious circle of fragmentation. Fabio Vighi in On Zizek;s Dialectics: Surplus, Subtraction, Sublimation finds that the postmodern Lacanian subject's insanity is greatly influenced by the deceiving fallacy of the Other. The pouring of master signifiers by the big Other into the mind of the subject is intended to give a phantasm of fullness and "an illusion of consistency" thus twisting the ugly Real; "What does a mastersignifier do? It quilts all the floating elements of the signifying chain, retroactively creating the necessary illusion that they were always linked in some kind of meaningful and consistent linearity" (105). This is manifested as Kane's subject cries out:

To my mind that's betrayal. And my mind is the subject of these bewildered fragments.

Nothing can extinguish my anger.

And nothing can restore my faith.

This is not a world in which I wish to live. (6)

Anger and frustration have fueled aggressiveness in Kane's character driving her to cut herself and revolt against her world. She expresses her desire to take an overdose, slash her wrists and hang herself, out of "dismay," "humiliation" and "depression." Carazo in "4.48 Psychosis: Sarah Kane's 'bewildered fragments"” states: "Although death drive is primarily turned not towards outside (as aggressivity) but towards the subject, that is, it is radically not a drive to 'murder', but a drive to "kill oneself"' (2). Hence, Carazo relates aggressivity to "self-loathing" and "self-discrimination" which leads to "self-inflicted pain" (2). In Ecrits: A Selection and under the title of "Aggressiveness in Psychoanalysis", Lacan asserts that aggresivity is rooted in "the images of castration, emasculation, mutilation, dismemberment, 
dislocation, evisceration, devouring, and bursting open of the body, in short, the imagoes that I have grouped together under the heading "imagoes of the fragmented body"'(85). Hence violence is manifested in dissevered parts of the body reflecting In-Yer-Face theatre.

Throughout the play, Sarah Kane's character is in a struggling journey inside her fissured mind hovering over undetermined borders. However, we came to a realization that what seems to be an aimless detour is in reality a pursuit for home and what appears to be a dreary desert seeker is in fact a yearning traveler striving for companionship and togetherness. The character claims; "When I walk out of here at the end of the day I need to go home to my lover and relax. I need to be with my friends and relax. I need my friends to be really together" (27). Carazo in "4.48 Psychosis: Sarah Kane's 'bewildered fragments",

The poetic image of light which opens and closes Kane's work can be taken as a redemptive metaphor, one that would explain why, after all the display of destructive feelings about herself and the emotional chaos brought about by depression, the woman culminates her elegy by asserting her need for affection and self-recognition: "the vital need for which I would die, to be loved." Because, in the end, beneath so much rage and brutality, beneath the crack of "these bewildered fragments" there lies a lyrical crave for love, one in which most of us will recognize ourselves. (7)

It is in only the image of "love" that we can find wholeness and accord and despite of a surface gushing with fragmentation, brutality and animosity; a powerful stream of affections and compassion encompasses us. With the final line "Please, open the curtains" Carazo believes that that it is an invitation to reconcile with the outside world seeking reunion and assuring hope (7).

Throughout the fragmentary passages and perplexing labyrinth of aisles, quests are pressed with regards to intentions and destination of the tormented ruptured postmodern subject in 4.48 Psychosis. It is concluded that the subject is seeking unity with the other through fragmentation, accord through discord and affiliation through aggressiveness. The subject attempts to close all mind fissures with 
"love" as Karen Coats in "The Role of love in the Development of the Self: From Freud and Lacan to Children's Stories" states that "the fundamental gap between the subject and its world, or, to use Lacan's terminology, the gap between the subject and the Other, between the symbolic and real, is covered over by love" (51). Coats added that "the Lacanian self is ontologically grounded in love, and that love should be understood as a force that seeks to reunite that which has been separated" (52). The subject ventures to find a new meaning to its wholesome existence by diverging, dispelling, severing and dissemination. Coats asserts; "the self suffers the loss of love-objects as ideal, and builds its own ego from the bits and pieces that remain as the ideal shatters" and "hence, we strive towards unity while maintaining our separateness" (61).

The psychological ordeals of the Lacanian subjects in Kane's 4.48 Psychosis are deeply founded on language ruptures and this closely links theories of Lacan to poststructuralism with regards to the decentered postmodern subjects. Language inhabits the psychotic and speaks through him/her as his/her troubled unconscious becomes language itself. Since language signs are made of signifiers and signifieds which get disconnected and dispersed, signifiers dominate the unconscious. Hence the unconscious becomes equivalent to the signifier and the subject collapses to be a definition of it. The postmodern subject is equated to a void untethered sign with no meaning. Both language and subject overlap sharing a lot of common aspects; repetition of words is equal to doubling of subjects, prolixity of words is equivalent to multiplicity and neologism resembles hybridity. Moreover, the missing paternal signifier, "Name-of-thefather", is equal to the absence of a paternal figure from our life, triggering psychosis. As a result, ruptured language chains are dislodged indicating a ruptured psychotic mind and cessation of speech foreshadows the death of character. Having the mind seized by language and subjected to its commands, dwelling in its territories and controlling the flow of its signifiers, is a painful disturbing feature which strongly places both plays in the front stage of In-Yer-Face theatre. 


\section{Works Cited}

\section{Primary Sources}

Kane, Sarah. 4.48 Psychosis. London: Methuen,1999.

\section{Secondary Sources}

Blattes, Susan. "Is the Concept of 'Character' Still Relevant in Contemporary Drama?" Contemporary Drama in English: Drama and/after Postmodernism. Eds. Henke Christopher and Martin Middeke. Trier: Wissenschaftlicher Verlag Trier, 2007.

Carazo, Carolina Sanchez-Palencia. "4.48 Psychosis: Sarah Kane's bewildered fragments." Tikasense eBooks. 2013. Web. 26 Jan 2015.

Cermak, Ivo et al. "'4.48 Psychosis' as a Suicide Note of Sarah Kane?" Narrative and Memory. University of Huddersfield Repository. 2009. Web. 1 April 2018.

Chiesa, Lorenzo. Subjectivity and Otherness: A Philosophical Reading of Lacan. Massachusetts: Library of Congress, 2007.

Chramosilova, Martina. "Beyond the Suicidal Despair: An Analysis of Sarah Kane's 4.48 Psychosis." Masaryk University: Faculty of Arts. 2014. Web. 28 March 2018.

Corveleyn, Jozef and Paul Moyaert, eds. Psychosis: Phenomenological and Psychoanalytical Approaches .Leuven: Leuven University Press, 2003.

De Waelhens, Alphonse and Wilfred Ver Eecke. Phenomenology and Lacan on Schizophrenia: After the Decade of the Brain. Leuven: Leuven University Press, 2001.

Dickson, Andrew. "The Strange Thing is We Howled with Laughter." The Guardian. 2016. Web. 27 March 2018.

Fink, Bruce. A Clinical Introduction to Lacanian Psychoanalysis: Theory and Technique. Cambridge: Harvard University Press, 2009.

Grammatopoulos, Yannis. Above the Ground and Beneath the Clouds: Schizophrenia in Lacanian Psychoanalysis. London: Karnac Books Ltd, 2017.

Gritzner, Karoline. "Sarah Kane or how to "scrape a life out of the ruins'." Adorno and Modern Theatre: The Drama of the Damaged Self in 
Bond, Rudkin, Barker and Kane. Hampshire: Palgrave Macmillan, 2015.

Gutscher, Lea Jasmin. Revelation or Damnation: Depictions of Violence in Sarah Kane's Theatre. Hamburg: Anchor Academic Publishing, 2014.

Haatanen, Mariia. "The Effects of Medicalization, Medical Practices, and Mental Disorder on the Subjective Experience of the Self in Sarah Kane's 4.48 Psychosis." Tampere University: Institutional Repository.2015. Web. 27 March 2018.

Henke, Christoph and Martin Middeke, eds. Drama and (after) Postmodernism. Trier: Wissenschaftlicher Verlag Trier, 2007.

Holm, Lorens. "Space and its Assembled Subjects: The Neurotic, the Psychotic and the Pervert." Transgression: Towards an Expanded Field of Architecture. Ed. Louis Rice and David Littlefield. New York: Routledge, 2015.

"Jacques Lacan: The Subject of the Unconscious." Encyclopedia of Lacanian Psychoanalysis. 2006. Web. 26 Jan 2015.

Lacan, Jacques. Ecrits: A Selection. Trans. Bruce Fink. New York: W.W. Norton \& Company, 2006.

---. The Psychoses: The Seminar of Jacques Lacan. Ed. Jacques-Alain Miller. Trans. Russel Grigg. New York: W.W. Norton \& Company, 1993. Kindle file.

---. The Seminar of Jacques Lacan: Book XV: The Psychoanalytic Act: 1967-1968. Dublin Business School. Trans. Cormac Gallagher.2011. Web. 31 March, 2018.

---. The Sinthome: The Seminar of Jacques Lacan: Book XXIII. Ed. JacquesAlain Miller. Cambridge: Polity Press, 2016.

Larenas Rosa, Gabriel Nicolas. "Language of a Broken Mind: Suicidal Poetic Techniques and Dramatic Dialogue in 4.48 Psychosis." SCRIBD. Web. 1 April 2018.

Nobus, Dany. "Lacan's Science of the Subject: Between Linguistics and Topology." The Cambridge Companion to Lacan. Ed. Jean-Michel Rabaté. New York: Cambridge University Press, 2003.

Ovaska, Anna. "Sarah Kane's World of Depression: The Emergence and Experience of Mental Illness in 4.48 Psychosis." On-Culture. Web. 1 April 2018. 
Sierz, Aleks. In-Yer-Face Theatre. 2008. Web. 31 August, 2018.

Urban, Ken. "An Ethics of Catastrophe: The Theatre of Sarah Kane." A Journal of Performance and Art. 23.3 (2001): 36-46. Print.

Vighi, Fabio. On Zizek's Dialectics: Surplus, Subtraction, Sublimation. New York: Continuum International Publishing Group, 2010.

Wragg, Stephen. "Sentimentalism and In-Yer-Face Drama: Mark Ravenhill, Sarah Kane, and Anthony Neilson." Academia. 2015. Web. 27 Jan 2015.

Zevnik, Andreja. Lacan, Deleuze and World Politics: Rethinking the Ontology of the Political Subject. New York: Routledge, 201 